\title{
Ottoman Legacy and Oriental Self in Serbian Opera
}

\author{
Tatjana MARKOvić \\ Department of Musicology and Performance Studies \\ University of Music and Performing Arts Vienna \\ Sailerstätte 26, 1010 Vienna, Austria \\ E-mail:markovic@mdw.ac.at
}

(Received: March 2016; accepted: June 2016)

\begin{abstract}
Serbia was an Ottoman province for almost four centuries; after some rebellions, the First and Second Uprising, she received the status of autonomous principality in 1830, and became independent in 1878. Due to the historical and cultural circumstances, the first stage music form was komad s pevanjem (theater play with music numbers), following with the first operas only at the beginning of the twentieth century. Contrary to the usual practice to depict "golden age" of medieval national past, like in many other traditions of national opera, the earliest Serbian operas were dedicated to the recent past and coexistence with Ottomans. Thus the operas Na uran$k u$ (At dawn, 1904) by Stanislav Binički (1872-1942), Knez Ivo od Semberije (Prince Ivo of Semberia, 1911) by Isidor Bajić (1878-1915), both based on the libretti by the leading Serbian playwright Branislav Nušić, and also Zulumćar (The Hooligan, librettists: Svetozar Ćorović and Aleksa Šantić, 1927) by Petar Krstić (1877-1957), presented Serbia from the first decades of the nineteenth century. Later Serbian operas, among which is the most significant Koštana (1931, revised in 1940 and 1948) by Petar Konjović (1883-1970), composed after the theatre play under the same name by the author Borisav Stanković, shifts the focus of exoticism, presenting a life of a south-Serbian town in 1880. Local milieu of Vranje is depicted through tragic destiny of an enchanting beauty, a Roma singer Koštana, whose exoticism is coming from her belonging to the undesirable minority. These operas show how the national identity was constructed - by libretto, music and iconography - through Oriental Self. The language (marked by numerous Turkish loan words), musical (self)presentation and visual image of the main characters of the operas are identity signifiers, which show continuity as well as perception of the Ottoman cultural imperial legacy.
\end{abstract}

Keywords: Opera, orientalism, Serbian music, Ottoman Empire 
The Ottoman Empire was one of the world's most powerful and long-lasting imperial systems, which was established in the thirteenth century and was dissolved by abolishing of the sultanate in 1922. As a successor of the Roman and the Byzantine Empire, this Mediterranean territory included the Middle East, North Africa, as well as southeast Europe. ${ }^{1}$ Although a part of Europe, the Balkans were seen as the Other precisely because of their belonging to the Ottoman Empire:

In attempting to define what makes the Balkans distinct from the rest of Europe, one of the first elements that comes to mind is the length of time that the Balkans remained within the Ottoman Empire. Other parts of the Continent, such as Spain and Sicily, were absorbed onto Muslim states, but this occurred a relatively long time ago. By contrast, the Ottoman Empire had a presence in the Balkans until 1912-1913, or barely 100 years ago. [...] The Ottoman legacy is regarded in different ways in Europe and is most often rejected. However, the facts remain, obstinate and immutable. The Balkans are in Europe. The Balkans have an Ottoman past. ${ }^{2}$

Serbia, as a part of the Balkans, was divided between the Ottoman and Habsburg empires and, due to the great migrations for centuries, Serbs have been dispersed all over Europe. Serbia's culture is characterized by the imprint of both imperial legacies. The Ottoman rule lasted between 165 years (Petrovaradin, today Vojvodina 1526-1691, later a part of the Habsburg Monarchy), 348 (Belgrade 1459-1807) and almost 500 years (Niš 1385-1878).

The question of the Ottoman legacy has long been neglected and hardly ever discussed in musicology in relation to the music proper, especially in western Balkans. This "distancing the self from the Turkish (sic) other [...] also ensures that the complexities and hybridity contained in that imperial legacy is safely packed away in a place where it cannot threaten the nation's genealogical purity." ${ }^{3}$ It is, however, a part of a wider lack of research of the role of European imperialism in

1. By using a small instead of capital "s" in southeast Europe I express the conviction that the semantics of the fixed, essentialized historical and geographical spaces need to be reconsidered and replaced by the not capitalized names, having in mind their constructed and dynamic nature. Cf. Karl Kaser, Südosteuropäische Geschichte und Geschichtswissenschaft (Vienna etc.: Böhlau, $\left.{ }^{2} 2002\right), 22-23$; Sabine Rutar, "Introduction: Beyond the Balkans," in Beyond the Balkans. Towards and Inclusive History of Southeast Europe, ed. eadem (Vienna etc.: LIT Verlag, 2014), 7.

2. Bernard Lory, "The Ottoman legacy in the Balkans," in Entangled Histories of the Balkans, vol. 3: Shared Pasts, Disputed Legacies, ed. Rumen Daskalov and Alexander Vezenkov (Leiden: Brill, 2015), 355-405, here 355 .

3. Şunhaz Yilmaz and Ipek K. Yosmaoglu, "Fighting the Specters of the Past: Dilemmas of Ottoman Legacy in the Balkans and the Middle East," Middle Eastern Studies 44/5 (September 2008), 677-693, here 677. It is significant to notice that numerous scholars incorrectly refer to Turks or Turkey when considering the Ottomans or the Ottoman Empire: "The Ottoman Empire was not a 'Turkish Empire'. It was a multilingual, multireligious, and multicultural political system that is most appropriately to be compared to other empires that have existed throughout history. That Europeans consistently referred to the Ottoman Empire as Turkey and the Ottomans as Turks is revealing of European thought categories, but this venerable usage provides a 
the territories that were a part of empires. ${ }^{4}$ As some of the leading postcolonial scholars, like Gayatri Chakravorty Spivak and Edward Said, stressed the "imperial experience continues to influence attitudes, beliefs, cultures and practices in the modern world". 5

The Balkan people's attitude to their own past is certainly not monolithic and not exclusively negative, but the general evaluation of the entire period of the Ottoman rule as a "dark age" is prevailing in historiography, especially from the interwar period. ${ }^{6}$ So-called Europeanization meant for the former Ottoman lands direction to the west, including among others the system of education, musical performance practice, composition based on the western music theory, as well as opera as one of the main representative forms of the constructed "high" western culture.

Due to the mentioned historical circumstances, the Ottomans - mainly embodied in "Turkish" characters - were often a topic of works of arts, mainly presented as the Other in religious, military, or love relations. It was the case with numerous "Turkish" operas and other forms of music theater in the seventeenth-, eighteenth-, nineteenth-century European music, including in a somewhat different way the Balkan - Bulgarian, Croatian, Greek, Montenegrin, Serbian - operas. The mentioned difference exists due to the Ottoman legacy.

In this paper I am going to consider the Ottoman legacy in Serbian opera before World War II on the basis of its appropriation, resulting in specific Serbian (music) Orientalism, that is, the understanding of the Otherness in the context of southeast European cultural memory. "The Balkan region was marked by two crucial shared historical legacies: the Byzantine and the Ottoman, so that it would not be an exaggeration to say that the Balkans are, in fact, the Ottoman legacy." In accordance to that, i.e. due to the long-lasted coexistence, the Other is presented in a similar way in the textual narrative, as well as "sounded" by similar musical means as the Self in the given Serbian-Ottoman dichotomy.

procrustean mindset that seriously distorts Ottoman reality." Imperial Legacy: The Ottoman Imprint in the Balkans and the Middle East, ed. Carl L. Brown (New York: Columbia University Press, 1996), 19.

4. "Preface," in Colonialism and Welfare: Social Policy and the British Imperial Legacy, ed. James Midgley and David Piachaud (Cheltenham, Northampton, MA: Edward Elgar Publishing, 2011), xi.

5. Ibid., 2.

6. Let me mention, as an example, Jovan Dučić's (1871-1943) definition of the Balkans as backward Orient from his essay Gradovi i himere (Cities and chimaeras, 1940). The modernist poet and diplomat pointed out that there are two Orients - the Balkan and the Buddhist, whereby the former is defined in the following way: "The Balkan Orient: the cosmos has never yet seen such a misery. Even today it lacks its own civilization, its own morality, its own nature. [...] The Balkans are even today a true Turkish desert." Jovan Dučić, Gradovi i himere (Beograd: Srpska književna zadruga, 1940), 117. Dučić was born in Trebinje, Herzegovina, as a Bosnian Serb. After his studies in Geneva and Paris, following the foundation of the first Yugoslav state, he served as the country's diplomat in Bucarest, Istanbul, Sofia, Rome, Athens, Cairo, Madrid and Istanbul. He was a distinguished author, mainly poet, one of the main representatives of Serbian Modernism, that is, the leading Symbolist. His opinion was a result of his life and work in the Ottoman Bosnia and Herzegovina, as well as in other Balkan countries, seen through his life in European cities.

7. Maria Todorova, Balkan Identities: Nation and Memory (London: Hurst and Company, 2004), 12. 
The operas were analyzed from the perspective of the Ottoman historical legacy in its different forms. ${ }^{8}$ My theoretical departure point is the definition of the imperial legacy formulated and revisioned by Maria Todorova and other historians: ${ }^{9}$ it is considered through the dynamic processes of appropriation. Defining the Balkans as the Ottoman (Turkish, as well as Arabic and Persian) legacy, Todorova develops the theory on imperial legacy as continuity and as perception. These two categories are not strictly divided and do not simply have "'real' versus 'imagined' characteristics," ${ }^{\prime 10}$ as the investigation of operas will show too. ${ }^{11}$

Broadly speaking, cultural appropriation is defined as "the use of a culture's symbols, artifacts, genres rituals, or technologies by members of another culture, is inescapable when cultures come into contact, including virtual or representational contact". ${ }^{12}$ According to the numerous definitions in literature, Rogers made a typology of the cultural appropriation: cultural exchange, cultural dominance (including cultural resistance), cultural exploitation and transculturation. ${ }^{13}$

Since one of the main characteristics of the Balkans and, in this framework, of Serbia, is its heterogeneity, marked by multi-cultural, multi-ethnic, multi-religious, multi-lingual context/s, the appropriation of the imperial legacies - in this case Ottoman - was processed through transculturation, ${ }^{14}$ having as a result recognizable Balkan hybrid cultures. The Ottoman legacy will be therefore considered in the coordinates of continuity and perception of the legacy, on one hand, and its appropriation as transculturation, on the other, first of all in the realm of literature, to be followed by opera.

8. By doing this, I support the urge of contextualizing the Balkan Studies in the Middle East or Anatolia and to include it in the field of musicology, especially opera studies. Cf. Karl Kaser, Balkan und Naher Osten. Einführung in eine gemeinsame Geschichte (Vienna etc.: Böhlau, 2011); Alexander Vezenkov, "History Against Geography: Should we Always Think of the Balkans as Part of Europe?", in History and Judgement. Junior Visiting fellow conference, vol. 21, ed. Alice MacLachlan and Ingvild Torsen (Vienna: IWM, 2006, online edition http://www.iwm.at/publications/5-junior-visiting-fellows-conferences/vol-xxi/alexander-vezenkov/).

9. The Ottoman legacy in the Balkans is defined in Maria Todorova, "The Ottoman legacies in the Balkans," in Imperial Legacy, 45-77; eadem, Imagining the Balkans (Oxford, New York: Oxford University Press, 1997, updated edition 2009); eadem, „The Balkans as Category of Analysis: Border, Space,” Archiv für österreichische Geschichte 137 (2002), 57-83; Todorova, Balkan Identities.

10. Todorova, Balkan Identities, 12.

11. Similar to Todorova's, there is the theory by Hercules Millas, proposing the actual versus the believed legacy. Cf. Hercules Millas, "Ethnic Identity and Nation Building. On the Byzantine and Ottoman Historical Legacies," in Europe and the Historical Legacies in the Balkans, ed. Raymond Detrez and Barbara Segaert (Brussels: P. I. E. Peter Lang, 2008), 17-32.

12. Richard A. Rogers, "From Cultural Exchange to Transculturation: A Review and Reconceptualization of Cultural Appropriation," Communication Theory 16 (2006), 474-503, here 474.

13. Ibid., 477.

14. The term was coined by the Cuban scholar Fernando Otiz in the 1940s, and here is used in accordance with Roger's synthesis, referring to "cultural elements created from and/or by multiple cultures, such that identification of a single originating culture is problematic, for example, multiple cultural appropriations structured in the dynamics of globalization and transnational capitalism creating hybrid forms". Ibid. 
It is important to stress that the Ottoman legacy was already rooted in Serbian literature, in numerous poems, short stories and novels, as well as in the language proper before the first operas were composed. One of the first and the most significant representatives of oriental ballad (artistic sevdalinka, which will be explained later) was Jovan Ilić (1824-1901). This politician - minister of justice and state secretary - was also the first significant poet, who was born in Serbia and lived in Belgrade. Majority of later poets and composers in the nineteenth century were from the Habsburg Monarchy (Vojvodina). Some poems from Jovan Ilić's collection Dahire (Tambourine, 1891) were published partly in the Turkish language. ${ }^{15}$ Ilić's house functioned as a literary club in Belgrade in the 1880s due to him and his sons, Milutin, Dragutin, Vojislav and Žarko, who were also authors and poets. The most significant nineteenth-century Serbian authors, playwrights and poets, who also visited Ilić's house, like Jovan Jovanović Zmaj (1833-1904) or Branislav Nušić (1864-1938), and composers, such as Josif Marinković (1851-1931), Stevan Mokranjac (1856-1914), Stanislav Binički (1872-1942), contributed to the tradition of sevdalinka, which hence entered the national classical music history. Interestingly enough, the transmission of the oriental poetry was often mediated by the works and translation of German poets, such as August von Platen (1796-1835), Georg Friedrich Daumer (1800-1875), or Friedrich von Bodenstedt (1819-1892), especially in the case of Jovanović.

The most significant Serbian playwright, Branislav Nušić (1864-1938), who was a consul in the Ottoman Empire (in Kosovo) was also very inspired by the Ottoman way of life and literature in his short stories, ${ }^{16}$ theater plays as well as in libretti of the two earliest Serbian operas. Consequently, contrary to the usual practice to depict "golden age" of medieval national past, like in many other traditions of national opera, the earliest Serbian operas were dedicated to the recent past and coexistence with Ottomans. Thus the operas Na uranku (At dawn, 1904) by Stanislav Binički, Knez Ivo od Semberije (Prince Ivo of Semberia, 1911) by Isidor Bajić (1878-1915), both based on the libretti by Branislav Nušić, and also Zulumćar (The Tyrant, librettists: Svetozar Ćorović and Aleksa Šantić, 1927) by Petar Krstić (1877-1957), ${ }^{17}$ presented Serbia from the first decades of the nineteenth century. Later Serbian operas, among which is the most significant Koštana (1931, revised in 1940 and 1948) by Petar Konjović (1883-1970), composed after a thea-

15. The term dahire proper (or today daire in Serbian) is a Turkish loanword.

16. For instance, in his collection of short stories Ramazanske veceri (Ramadan evenings, 1898), dedicated to Jovan Ilić, he presented this world in a very warm and idyllic way, including singing of sevdalinka or playing saz.

17. Petar Krstić used the Arabic/Turkish loanword for the title of his opera: namely, 'zulum' means tyranny, injustice, and 'zulumćar' is a man who acts in that way, that is, a tyrant. Cf. Đorđe Popović, Rečnik turcizama (Belgrade: Partenon and Srpska književna zadruga, 2014), 310. The title of the opera is also translated as The Hooligan, cf. http://operadata.stanford.edu/catalog/10116687. 
tre play under the same name by the author Borisav Stanković (1876-1927), shifts the focus of exoticism, presenting a life of a south-Serbian town in 1880.

After establishing national literature, marked by the considered transcultural hybridity, ${ }^{18}$ the same process was noticeable in national opera, especially if we have in mind that texts by some of the mentioned authors were used as libretti of the "first national" operas. Analyzing operas in the given coordinates starts with the legacy as continuity. The Ottoman legacy as continuity is a process "that begins after the Ottoman Empire ceased to exist for particular regions which shaped themselves into successors states" and is the "aggregate of characteristics handed down chiefly from the historical situation of the eighteenth and nineteenth centuries". ${ }^{19}$

A few elements we can possibly designate as Ottoman legacy as continuity, although some were later re-contextualized and received the status of the legacy as perception. They could be defined at the level of the constituent elements of opera (in libretto, music and iconography). Among them are numerous Turkish/Persian loanwords (libretto), certain Middle East scales or makams (music) and material culture related to clothing, footwear, food (iconography) known the Ottoman traditions. These signifiers of collective Serbian identity explicates the process of transculturation "by which a cultural form (e.g. language, food, music) moves from one physical location to another where it interacts with and influences the local forms (languages, food, music, etc.) and produces new cultural hybrids". ${ }^{20}$ Tellingly, it was precisely the case in the opera Knez Ivo od Semberije (Prince Ivo of Semberia): the serfs wear the felt Bosnian clothes, the fez on head with a saruk (a kind of turban around it), red jemenijas (a kind of light shoes or slippers), and they smoke short Turkish pipe. The key signifiers of "Oriental" or Ottoman everyday life, smoking and drinking coffee, are also included in the opera: Prince Ivo's people wait for Kulin and, as for a sign of their hospitality, they offer him a cup of coffee in fildžan (traditional Turkish cups) and a pipe called čibuk (çibuk). ${ }^{21}$

The description of clothes named after the Turkish model, which was adopted from the Ottoman culture, is visible on the stage but not heard in music, since it is only mentioned in the notes included in the score as an instruction for costume designer, this very encounter of the Serbian governor of Semberija and a hero with his Ottoman counterpart is composed as a dialog scene followed by a dance of

18. As James Lull pointed out, transculturation "produces cultural hybrids - the fusing of cultural forms." Cf. James Lull, Media, Communication, Culture (Cambridge: Polity Press, ${ }^{22000), ~} 243$.

19. Todorova, "The Balkans as Category of Analysis," 64.

20. Lull, Media, Communication, Culture, 252.

21. Coffee achieved the status of the most important place in the Ottoman culture of drinking and its consuming caused some changes in everyday life of common people. As Otto von Pirch described his meeting with Hussein Pasha in Belgrade in his travelogue Reise in Serbien im Spätherbst 1829, smoking of aromatized tobacco along with drinking coffee was quite usual: "As the Turks normally swallow the smoke, they say: coffee and čibuk are to be drunk". Oto Dubislav plem. Pirh. Putovanje po Srbiji u godini 1829, transl. Dragiša J. Mijušković (Belgrade: Akademija nauka, 1899), 21. Cf. also Marija Kocić, Orijentalizacija materijalne kulture na Balkanu. Osmanski period XV-XIX vek (Belgrade: Hesperiaedu, 2010), 341 and 357. 
harem women travelling as Kulin Ban's accompaniment. They entertain the two rulers by a performance of the Ottoman dance čoček, which was also adopted via transcultural processes and shifted through the ages as a dance characteristic for southern Serbia. The using Igra čočeka (Dance of čoček) as the Ottoman identity signifier is interesting because it shows the early period of development of the dance, today recognized mainly as a part of Roma music tradition. Čoček is also a part of history of Ottoman military bands and it emerged as a dance in the Balkans at the beginning of the nineteenth century, precisely in the period when the action of the opera is taking place. This dance was defined as a female improvised dance, "utilizing hand movements, contractions of the abdomen, shoulder shakes, movement of isolated body parts (such as hips and head), and small footwork patterns [...] but its subtlety and restraint distinguish it from contemporary belly dancing". ${ }^{22}$ The dance scene of čoček (Scene 7) in Bajić's opera is introduced at the moment when Kulin-Beg comes to visit Prince Ivo. It is in characteristic $3 / 4+3 / 8$ meter, contains three parts A B A1, based on transposition of the same two-measures phrases respectively. Additionally to the punctuated rhythm, at the beginning of short phrases, the recognizable oriental sound is present due to the augmented second in melody. It is noteworthy that Bajić included trumpet players at the stage on the occasion of appearance of Turks with slaves instead of drums and zurnas indicated in the drama served as a basis of the libretto. Music of the čoček explicates the ambiguous status of the dance, which intermingles continuity and perception of the Ottoman legacy. While its historical background, cultural context, performance practice (female dancers) could be understood as the former, its place and role in the opera however does not embody Ottoman sound, but a Verdian instrumental piece referring to the "Orient".

Three operas, At dawn, Prince Ivo of Semberia, and The tyrant, are witnessing one more aspect of continuity assimilated through historical social practices and chosen as the representative of the Ottoman cultural identity: muezzin's call for prayer. Branislav Nušić, the librettist of the two former operas, indicated a muezzin's call at the beginning of the works as a recognizable signifier of the given historical context and a background of the operas' plot. The call for prayer is integrated into the operas seemingly as a "direct" transposition of a form of contemporary cultural practice. ${ }^{23} \mathrm{~A}$ richly melismatic, ornamented melody of a solo voice with the words "Alah ekber" (Allah akbar) or "Alah je silan" (Alah is mighty) is given either in alternation with the fragments of the imaginary (Serbian) folk dance from the central genre scene (At dawn) or with the imaginary

22. Carol Silverman, "The Gender of the Profession," in Music and Gender: Perspectives from the Mediterranean, ed. Tullia Magrini (Chicago: The University of Chicago Press, 2006), 127.

23. As it was mentioned, the action of Binički's and Bajić's operas is placed in Serbia and Semberia in the first half of the nineteenth century, that is, in the recent past. The operas were composed around thirty years after the liberation of Serbia (1878). 
Orthodox choral singing (Prince Ivo of Semberia). Additionally, in both cases, the muezzin's call is "explained" by spoken words: in the Binički's opera, Stanka says: "Muezzin finished his prayer and his greeting to God," and in Bajićs an anonymous member of the Serbian society (choir) points out: "Two religions are fighting here". In that way, the "Oriental melody" with recognisable augmented seconds is positioned as textual-musical designation of the operas' plot context. A muezzin's call for prayer is included in Petar Krstić's opera The tyrant, too, moreover in a very similar way to the mentioned earlier stage works. It is treated as a legacy as continuity, although the opera was produced between two world wars.

$$
* * *
$$

Understandably, there are much more elements showing the Ottoman legacy as perception. This is the process of interaction between "an ever-evolving and accumulating past, and ever-evolving and accumulating perceptions of generations of people who are redefining their evaluations of the past" (Todorova) established after the Treaty of Berlin (1878), when Serbia gained independence. ${ }^{24}$ Since the legacy as perception is not reconstructing, but constructing past, its appropriation was shifted through history. While in the period of the nineteenth century (until 1914) the Ottoman legacy was assimilated and resulted in a hybrid culture, in the age of Modernism, the transcultural merging of cultures was defined as "authentic" national. It was the case how the čoček was treated in Koštana. Additionally, the sevdalinka, rooted in Ottoman Bosnia, developed as a form of tavern music, was integrated into opera due to Branislav Nušić and Stanislav Binički as an an example par excellence for legacy as perception.

One of the most popular Serbian theater plays (with music numbers), Koštana (1899) by Borisav Stanković, was a basis for the opera with the same name by the librettist and composer Petar Konjović. The extraordinary popularity of the theater play Koštana is due to folk elements strongly connected with the Ottoman heritage (the story takes place in a small town and includes many local features, including traditional clothes this time too, quotations of several well-known folk songs, among which some of sevdalinka type): the playwright precisely determined which folk songs should be performed, and Konjović, who himself wrote the libretto, also included folk songs performed by Koštana and other Roma musicians. The driving force in the plot is the singing of the fatally attractive Gipsy girl, Koštana. With her magic voice she enchanted the entire town, but at the same time invoked her own tragedy: since her beauty disturbed the village and her origin was an obstacle to her marrying the man whom she loved (Stojan from a rich family), she was forced to marry a much younger mute and insane boy. In order 
to provide a correct pronunciation of the specific dialect from southern Serbia characteristic after numerous Turkish loanwords, the composer used declamation. His aim was to enable insight in inner state of the characters by quoting stylized folk melodies, their fragments, or composing imaginary folk music. Therefore he modified Stankovićs text and added an entirely new scene highlighting psychological profile of Koštana, and also pervaded entire score with folk or folklike sounds. Konjović actually started investigating characteristics of (Slavic) folk melodies already during his studies in Prague, where he learned about collections of folk songs by Vítezslav Novák and Mikulás Schneider-Trnavski which inspired him also to collect folk melodies. In his study about Koštana, the composer explained the process of his own work with the chosen folk songs:

before composing my third opera (Koštana), I transcribed, studied, and laid down as artistic material folk motives of our South, and later of all other parts of Yugoslavia; three fifths of them I published [arranged] for voice and piano under the title Moja zemlja (My country). Already then, I chose among those motives musical lines which seemed appropriate for inclusion to a free artistic expression. From there I began searching for rhythmic and harmonic specifics hidden [...] in the true melodic and motivic core of those songs. Balkan South Slavonic folklore is capable of providing not only exoticism, but also powerful and characteristic elements in music, the expression accessible to the general artistic standpoints, what has been proven in my Koštana. ${ }^{25}$

By this time the loanwords were fully adopted, forming a specific south Serbian dialect existing until today, reaching a status of national language. Consequently, the Ottoman legacy was by music transformed into a signifier of Serbian national i.e. Slavic identity and, through this process of transculturation, lost its direct connection with the original context, enriching the hybridity of the south Serbian culture.

This opera also includes a scene of dancing čoček but, in accordance to the shifted legacy, in a rather different way: it is regarded by the composer as "authentic" south-Serbian dance. It is written as an extended horovod scene (genre scene with choral singing and dancing of folk music), like in various Russian operas. The presence of the Ottoman legacy remained in iconography of the opera due to the traditional costumes.

25. Petar Konjović, "Razgovori o Koštani," Knjiga o muzici srpskoj i slavenskoj (Novi Sad: Matica Srpska, 1947), 109. 
The most prominent form of considered imperial legacy as perception is undoubtedly sevdalinka, ${ }^{26}$ an urban song of mainly love content ${ }^{27}$ from the Ottoman period of Bosnia and Herzegovina (from the fifteenth to the nineteenth century). ${ }^{28}$ Due to the process of acculturation, it was accepted and cherished among all South Slavs at the Balkans. Sevdalinka is regarded first of all as a musical, vocal genre, ${ }^{29}$ and it has been performed by a solo singer with instrumental accompaniment. During the Ottoman period, the most often used instrument was saz (Near East instrument, a type of long-necked lute with 9-12 strings) and later on accordion, and instrumental ensemble. This strophic narrative song of melancholic character is recognizable after its melismatic melody in one of the (mainly minor) modes of the makam system ${ }^{30}$ or, as Vlado Milošević claimed, Mixolydian, major and minor scales, chromatic alternation, in slower tempo. The most important aspect of sevdalinka is the interpretation or very expressive singing, as well as the main signifier of Oriental music - augmented second. ${ }^{31}$

Nušić's and Binički's very idea to include a sevdalinka into the opera most probably came from their intention to provide communication with the audience. What was specific here is the fact that this emotional and expressive sevdalinka is given to the Turk Redžep, who is suffering from his love to the Serbian girl Stanka in the opera. Although she rejected him because of her love for Rade, a Serbian man, and their wedding plans, the Turk's longing love song presents him by no means in a negative light, quite the opposite to the western operas.

All the sevdalinkas in art music are recognizable after their expressiveness and full emotional pathos due to the Oriental musical means, among which the augmented second has a special role. However, it is a constructed idea on the Ottoman music. As Stevan Mokranjac and later on his student, the composer Petar Krstić stated in their writings and confirmed, like the mentioned opera composers, by their music proper, the characteristic scale of Serbian folk tunes is Balkan mode,

26. Its analogue genre in Greece is rebetika.

27. Until the end of the nineteenth century, the urban song from Bosnia and Herzegovina was known under various names: šeherske or šeherli (šeher means "city”) songs, dilberke (dilber means "dear"), ašiklije (ašikovati means "to woo"), harem songs, turčije or Turkish songs. It received its current name after the Arabic word sevda (transformed to sevdah), meaning love longing, most probably after Gipsy musicians named it. Cf. Vlado Milošević, Sevdalinka (Banja Luka: Muzej Bosanske krajine, 1964).

28. Sevdalinka remained popular also during the Austro-Hungarian annexation of Bosnia and Herzegovina (1878), as well as in Yugoslav states until today. More precisely, as Pennanen pointed out, sevdalinka can be defined as "Ottoman Turkish and especially Bosnian-Herzegovinian Muslim non-religious urban songs." Cf. Risto Pekka Pennanen, "Melancholic airs of the Orient - Bosnian sevdalinka music as an orientalist and national symbol," in Music and Emotions, ed. Risto Pekka Pennanen (Helsinki: Helsinki Collegium for Advanced Studies, 2010), 76.

29. The spreading of sevdalinka was enabled by the early music recordings and finally, in Tito's Yugoslavia, it became a professional music genre, present at festivals, radio shows, and solo concerts, resulting in appearance of specialized sevdalinka singers, who were famous not only inside the borders of Yugoslavia, but in entire Europe, even in the U.S. Among them was, for instance, Sofka Nikolić, who made international career.

30. Pennanen, "Melancholic Airs of the Orient," 78.

31. Milošević, Sevdalinka, 32. 
sometimes also the so-called Gipsy mode, and rarely the Hijaz mode. "A huge gap separates the imagined Oriental music from what Ottoman makams and their folk equivalents actually are and how they function." ${ }^{32}$ In other words, in spite of the fact that the augmented second represents the Orient

it is not omnipresent in Ottoman classical music or other forms of Turkish music. As we shall see below, the absence of this emblematic interval usually leads Balkan scholars to switch to Occidentalist discourse and analyse makam melodies through "ancient Greek modes," or more properly church modes. ${ }^{33}$

Similarly, the most prominent southeast European music historiographer, Franz Koch alias Franjo Kuhač from Croatia, claimed that the augmented second is actually an authentic signifier of the regional music, which was overtaken by the Ottomans.

Due to this fact, the two worlds (Serbian-Ottoman) in both operas are not musically strictly separated (for instance, the motive of Prince Ivo at the very beginning of Bajić's opera with augmented second). This confirms the opinion that exotic does not mean

merely distant (indeed, distance is not even a necessary prerequisite) [...] The exotic equation, therefore, goes well beyond familiar versus unfamiliar, and it is in large part the attendant cultural connections, tensions, and suggestions that make such stylistic blends as compelling, alluring, and ultimately troubling as they are [...] Exoticism is not about the earnest study of foreign cultures; it is about drama, effect, and evocation. ${ }^{34}$

In the age of Modernism, however, the same musical mean was defined as characteristic for Serbian traditional music, in the context of ideology of Orientalism. Hence, Petar Krstić claimed:

The most characteristic scale of Serbian folk melodies is "Oriental minor". The melodies are short, including mainly eight and rarely up to sixteen bars. Their range remains within sixth, sometimes within an octave, and if they reach the seventh, than it is the minor (Mixolydian) seventh. Serbian folk melodies are in all possible scales, most often in Oriental minor (Balkan minor). This fact

32. Risto Pekka Pennanen, "Lost in Scales: Balkan Folk Music Research and the Ottoman Legacy," Muzikologija/Musicology 8 (2008), 127-147, here 146.

33. Ibid., 131.

34. Jonathan Bellman, "Introduction," in The Exotic Western Music, ed. idem (Boston: Northern University Press, 1998), xii-xiii. 
proves that the augmented second, recognized as the main characteristic of the Oriental music, actually is not a foreign element, but it is "ours". ${ }^{35}$

This quotation shows the same redefinition of the legacy with changed perception from the clear relation to the Middle East music to a signifier of national music in the interwar period. Additionally to the "oriental" legacy, the operas after World War I show more obvious composers' orientation to the Slavic (Bohemian/ Czech, Russian) impact too, which resulted in a specific musical hybridity.

The fact that in the same opera, as well as in the operas from different historical periods, it is possible to designate both legacy as continuity and perception proves not only that the division between the two is not strict, but also that Todorova's idea to give them in chronological order (perception is characteristic for the time after the liberation from the Ottomans) is not quite sustainable.

As the consideration of the Ottoman imperial legacy in music explicates, the "Orient" in Serbian and Balkan literature, paintings and music was not, like in the west, some imagined, distant unknown exotic place, but a part of their own cultural space. In this case, hybridity "involves the fusion of two hitherto relatively distinct forms, styles, or identities, cross-cultural contact, which often occurs across national borders as well as cross cultural boundaries". ${ }^{36}$ It shows another way of constructing nationalism as a legacy of imperialism. The approach and definition of the imperial legacy was rather different in the period before and after World War I and contributed to the hybrid culture, especially if it is understood as a network of different cultures.

35. P. J. Krstić, “Opet o harmoniziranju narodnih melodija,” Muzički glasnik 19 (October 1922), 1-2, here 1. 36. Marwan M. Kraidy, Hybridity, or the Cultural Logic of Globalization (Philadelphia: Temple University Press, 2005), 5. The postcolonial turn took up hybridity as a central dimension of the literary and cultural productions of Africa, Latin America, Asia, and diasporas in the West. However, since the Balkans are positioned at the crossroad between empires and their cultures for centuries, the concept of hybridity can be taken as a convincing theoretical tool for consideration of its multiculturalism and imperial legacies. 